\title{
Political-Economic Indicators for Self-Sustainability in Greenland
}

\author{
Christian Wennecke \\ Greenland Business
}

\begin{abstract}
This article contributes to policy learning in Greenland by linking entrepreneurship and innovation system theory to recent and former attempts at creating political-economic indicators. The article shows how working methods have developed within the Greenland government where evidence-based governance is becoming more commonly used. The main findings indicate that the overall political objective of creating a self-sustaining economy is not possible in the short run, but is a politically meaningful overall goal. Existing measurements and indicators have been important instruments in developing an understanding of the connectedness of elements in the innovation system. Measurements and indicators could still be developed further, especially by extending with more individual level data that can be analyzed within the context of institutional level data. Also, the natural resource sectors need to be thought about in connection to other industries and the competencies of the population in order to avoid a resource curse. This could very well be done in a cross-sectional innovation policy, perhaps including an indicator for "self-sustainability," and combined with measuring the actual development in comparison with the set goals.
\end{abstract}




\section{Introduction}

Greenland is an autonomous territory within the Kingdom of Denmark and has a colonial history that goes back 300 years. The vast majority of the small Greenlandic population, numbering roughly 57,000 people, descend from Thule culture Inuit who arrived to the lands from the northwest 1,000 years ago. At approximately the same time, Scandinavians coming from Iceland settled in the south. The most famous of these was Eric the Red, who gave the land its European name. It was in search for the old Scandinavian settlers that Hans Egede came to Greenland in the eighteenth century. He only found Inuit, but established the colony of Godthåb (Nuuk) in 1728, thus commencing the modern colonization of Greenland.

Today, Greenlanders are still striving for independence but have had autonomy since 1979 when "home rule" was enacted. Autonomy was extended in 2009 when the current self-rule system was established. The official language is now Western Greenlandic (Kalaallisut), and the official name of the land is Kalaallit Nunaat (the land of the Greenlanders). The Kalaallit are recognized as an Indigenous people in their own right, but this has not always been the case and attempts to suppress the Inuit culture have been made. Still, many ties of family and friendship exist with Danish people, which often makes the talk of separation a very emotional one.

The political independence from Denmark requires economic independence, which would mean the substitution of the "block grant" which is a state subsidy received from Denmark every year - with national production, while also ensuring a sustainable economy. Meanwhile, there are important demographic changes going on in Greenland. The population is stagnant (or even decreasing a little), it is getting older, more concentrated around towns, and there is a tendency for brain drain. Because of this, the Economic Council (2014) presages the necessity for major improvements of the public finances and wider economic reform in order to retain a solid economy.

The economy of Greenland depends heavily on fisheries and the state subsidy from Denmark. According to a report from Copenhagen Economics (2013), made for the Greenlandic Employers Association, the fisheries account for $13 \%$ of Greenland's GDP and another $12 \%$ is generated indirectly by the fisheries through investment and household spending of fishermen. It is important to note that GDP in Greenland does not account for the whole economy because the block grant from 
Denmark is not included. The GDP is roughly 1.8 billion euros $(€)$, and the block grant is another 610 million euros $(€)$ on top of that (see below).

Achieving the economic and political goals is a huge task, and since the fisheries are nearly exploited to the maximum, a diversification of the economy and establishment of high value-added industry are much needed. The quest for this holy grail of the economy has been followed by political-economic indicators for more than a decade.

In the 2003 report of the Joint Committee for Business Development in Greenland (Joint Committee, 2003), a number of political-economic indicators were set as targets for Greenland by 2014. The statistical data for 2003-2014 has recently been made available by Greenland Statistics and other organizations, making it possible to see which of these targets have been reached. More currently, the Government of Greenland (Naalakkersuisut) issued the recent Political-Economic Report (2016), which includes a "Sustainability and Growth Plan." In this report, indicators for development in a number of areas are suggested to be achieved in the coming ten to fifteen years. With a new set of indicators published, it is the purpose of this study to compare the two reports in order to evaluate the status and development of the way political-economic indicators are used in policy making.

This article will explore the actual and potential role of politicaleconomic indicators in making Greenland's economy more selfsustaining. This is done by comparing the first and last cases of the use of political-economic indicators, thereby showing that there has been a policy learning process going on within the government.

This article is primarily empirical, but by including a bit of theory I am also able to offer a few suggestions for further policy learning. The research draws on both innovation systems studies and entrepreneurship studies. These are generally considered to be two distinct fields of study, and combining them makes it difficult to contribute to either field. The purpose of the study is not so much theory development as it is the practical application of theory in policy making. The theories will be combined in search of a prescriptive background for the development of the use of political-economic indicators in a natural resource intensive economy.

The specific traits of the Greenlandic society, a very small population living in small isolated communities spread across the world's largest island, might be a problem when using theories developed elsewhere. It could be possible to solve this problem by including studies of the adaptive capacities of a relatively small, isolated population with lower 
levels of education. There is a tendency in Greenland to imitate the policies of Denmark and the West, but there is an unsolved question of whether this is the best for Greenland, and whether Greenland is at all ready for this. This is something that can be considered for the future work with economic indicators in Greenland.

\section{Innovation and Entrepreneurship Studies}

By suggesting that political-economic indicators should address the dispositions of individuals towards entrepreneurship and innovation, as well as the institutional settings in which they happen, this article positions itself between innovation studies and entrepreneurship studies. Landström (2013) argues that though innovation studies and entrepreneurship studies have developed from the same source, they have developed into two separate fields with little likelihood that they will move closer toeach other. When combining theories thatare different, theapproach becomes eclectic. This can be acceptable when studying a phenomenon openly rather than testing the validity of the theory (Davidsson, 2016). Within the National Systems of Entrepreneurship approach, Zoltan Ács (2014) brings innovation and entrepreneurship thinking together. This is done by combining the institutional approach of innovation systems studies with the individual approach of entrepreneurship studies. This work has resulted in the Global Entrepreneurship and Development Index (GEDI). This is equally an eclectic approach, but it is suitable for the policy-making purpose.

Joseph Schumpeter (1942) was the first to describe how innovation drives economic change. When innovation creates new opportunities it follows that "Creative Destruction" renders old opportunities obsolete. Since this conceptualization, innovation studies has criticized neo-classical economics for being a static and unrealistic mathematical reproduction of reality and based on assumptions that cannot be demonstrated empirically. This is seen in Nelson and Winter's critique of the so-called "rational behaviour" in their 1982 work "Evolutionary Theory of Economic Change," which according to Landström figures as a core work for both innovation and entrepreneurship studies (Fagerberg, 2013; Landström, 2013).

Since the late 1980s, innovation studies accelerated not least with the concept of "National Innovation Systems," which provided an interactive view on innovation that was much broader than the former "linear model" where innovation is seen as new technology leading to economic change. Competencies within high-tech as well as low-tech sectors became 
an important driver of economic development as well (Lundvall, 2007; Fagerberg, 2013). In entrepreneurship studies, knowledge has become the predominant production factor with the rise of globalization and the development of the knowledge society. As a result, entrepreneurs started to outperform large enterprises due to the volatility of knowledge as a production factor (Gilbert, 2004).

Today, innovation is studied at three levels of analysis: micro (innovation in companies), meso (systems of innovation), and macro (meaning of innovation in society). Innovation is measured on these three levels to find the drivers and prohibitors for innovation and, more recently, in policy learning (Strategic Innovation System Management) and development policies (Innovation Based Natural Resource Intensive Development) (Fagerberg, 2013; Andersen, 2015; Mytelka, 2002).

Innovation studies tend to focus on different types of "innovations" (e.g., product innovation, process innovation) and their outcomes (Fagerberg, 2013), whereas entrepreneurship studies tend to focus on the "competitive behaviours" of entrepreneurs and their outcomes (Davidsson, 2016). The GEDI uses an elaborated version of Davidsson's definition, where behaviour is described as attitudes, abilities, and aspirations (Ács, 2016). One important difference in innovation and entrepreneurship studies is whether innovation is seen as caused by an institutional setting (innovation studies) or as caused by the actions of entrepreneurs (entrepreneurship studies); the role of the innovator seems to be black-boxed in innovation studies, whereas the big picture seems to be downplayed in entrepreneurship studies.

In the following section, a subfield of innovation systems and a subfield of entrepreneurship will be presented. They provide a framework for building political-economic indicators in a natural resource intense economy. In this eclectic approach, the macro-level pertains to the connection of innovation to the resources that are the economic foundation of society. The micro-level is the attitude, ability, and aspiration of individuals to change the way things are, and the meso-level is the

policy making that connects the two other levels into a hopefully fruitful development.

\subsection{Innovation Based Natural Resource Intensive Development}

When exploiting natural resources, it is important to be aware of, and avoid, the "natural resource curse." The resource curse accounts for the fact that the exploitation of natural resources has not always led to favourable economic development. According to the Economic Council 
of Greenland (2012), tight political control is the solution. Due to the dominance of fisheries in the economy, the resource curse is already a risk, and the risk will increase in strength with the engagement in large and isolated resource projects.

The main challenges for natural resource projects are (Economic Council of Greenland, 2012):

- Natural resources are very expensive to extract and transport, making the potential resource rent relatively small.

- Price volatility presents a risk to investment in natural resources, and with a high cost structure the risk of the investment is higher.

- Mineral resources are also exhaustible, posing a challenge to politicians to wisely reinvest the revenues or see the benefits get eaten up by inflation.

- Overheating of the economy and tie-up of the workforce are risks that are present with any large-scale project in a small economy.

In contrast to this, is the desirable scenario of "Innovation-Based Natural Resource Intensive Development" (INRID), coined by the "Globelics" network (Andersen, 2015):

It is obviously not enough to have access to abundant natural resources. But if you can build an institutional framework for the utilization of specific natural resources, which supports development of new knowledge and competences, which may again be applied in a range of different activities, INRID may be possible. Therefore, the resource curse is not really about natural resources, but about learning-or the absence of it. Natural resources do not make countries poor, but weak innovation systems do. (p. 34)

INRID is about linkage deepening, which means building many strong linkages from the resource industry to other areas of society and other industries, such as:

- linkages to supplying service companies, and a processing industry;

- the migration of knowledge into other areas of society;

- creation of demand in the economy, and supplying something in demand; and

- creation of revenues in the form of taxes and royalties. 
A natural resource project with many strong linkages to the domestic market, local businesses, and knowledge institutions, will be more valuable to an economy than an isolated resource project that is at risk of leaving nothing but taxes and royalties behind.

\subsection{Global Entrepreneurship and Development Index}

An approach of focusing on the areas that are the most challenged is suggested by several scholars. Fagerberg (2015) calls it the "blocking mechanism," and Zoltán Ács (2014) calls it the "Penalty for Bottleneck" methodology. This is used in the National Systems of Entrepreneurship (NSE) approach. In this view, policy shapes the context for which entrepreneurial attitudes, abilities, and aspirations drive the allocation of resources through the creation and operation of new ventures. To measure a country's capacity to do this, Ács suggests a multi-faceted approach that provides appropriate contextualization and allows interaction between system components. This is done by combining a range of individual-level variables with another range of institutional variables. The institutional variables are mostly based on data made available from organizations like the OECD and the World Bank, whereas the individual variables are based on data from the Global Entrepreneurship Monitor (GEM) program. The GEDI is a super-index, with fourteen pillars divided over the three sub-indices "attitudes," "abilities," and "aspirations." Each pillar has an institutional-level variable and an individual-level variable (Figure 1). A pillar value is calculated from the two, and a bad score in one of them penalizes a good score in the other. The "bottlenecks" are then the weakest link in the national entrepreneurial dynamic, which can be pointed out analytically by the suggested measurement.

The unique feature of the GEDI is the combination of institutionallevel and individual-level variables. The approach seems to be eclectic and suitable for consulting policy makers, in contrast to the GEM which seems more suitable for scientific purposes. As we shall see, in Greenland there is a rather well-developed tradition for institutional-level indicators, but hardly any individual-level data exists. As an instrument for policy making, the GEDI seems to be the solution of choice for Greenland, but for the purpose of collecting the individual level data, an adapted GEM study would probably be the best solution. 


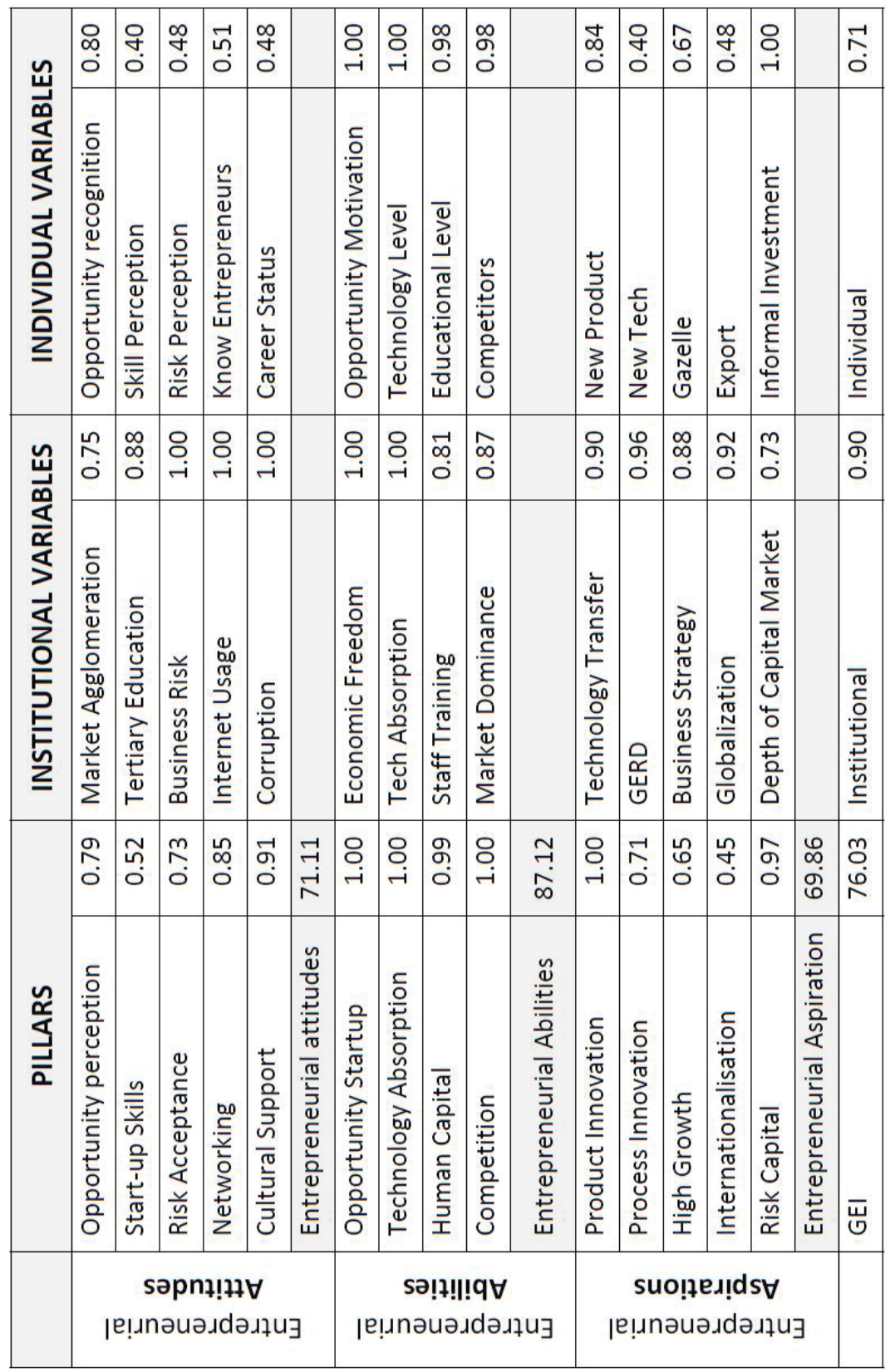

Figure 1. The GEDI scores for Denmark, 2015. Each pillar combines an institutional-level and individual-level variable. All pillars are combined in an overall "GEI" index. Denmark will gain most from focusing its innovation policy on internationalization and start-up skills. It is rather the peoples' self-efficacies, and not institutions', that need attention (Ács et al., 2016). 


\section{Independence and a Self-Sustaining Economy}

In 1953 Greenland was adopted by Denmark as a supposed equal part of the kingdom after having been a colony for a couple of centuries. In the following decades, many Greenlanders started protesting against being run from Copenhagen and in 1979 Greenland achieved "Home Rule" autonomy status. This was expanded into "Self Rule" in 2009, but many Greenlanders are still keen on completely liberating Greenland from Danish influence. Today, Greenland's economy depends on a major block grant from Denmark, which makes it very difficult to achieve independence without a remarkable change in living conditions. The amplitude of the economic barrier for independence will be assessed in the following.

The ambition of the Government of Greenland is to achieve more independence from Denmark. "How" and "when" they intend to achieve this is the question, not "if" they will attempt to do it. Nearly a hundred years ago, the discussions of when and how were not about the independence of Greenland, but rather the lifting of the isolation of Greenland that was maintained by the Danish state for centuries (Freuchen, 1931). Tupaarnaq Rosing Olsen (2005), a Greenlandic author and journalist, describes the political history of Greenland from 1939 to 1979, providing insight into the shaping of political thinking in Greenland and the emerging inclination for independence.

WWII helped to open the Greenlanders' eyes to the outside world. According to the Governance Act of 1925 it was the intention that the operation of Greenland should be economically self-contained, and that Greenland's economy should be a closed circuit, isolated from the outside world. WWII put an end to this model of governance. (p. 11, own translation)

The Siumut party has been the ruling party since the inauguration of home rule, except for one term. From 2009 to 2013, when the government was led by Inuit Ataqatigiit, Siumut was in opposition for the first time. The current premier, Kim Kielsen (Siumut party), has taken a different stance towards the discussion of independence compared to his predecessor Aleqa Hammond (Siumut) who proclaimed that Greenland would become independent in her lifetime. Premier Kielsen's government will take care of more acute problems, and is committed to creating better conditions for youth. In return, they should be committed to pursuing 
educational opportunities and it is hoped this will form the basis for a self-sustaining economy (Rottbøll, 2015).

In the latest edition of the annual "Political-Economic Report," the government's ambition is spelled out (Naalakkersuisut, 2016):

The Government of Greenland has a general vision ... that Greenland should gradually become more economically self-sustaining and in the long run become independent of the block grant from Denmark. (p. 27, own translation)

The term "self-sustaining" was used by Lars Emil Johansen (Siumut) in his opening speech for the Parliament's fall meeting in 1994 (Johansen, 1994). But it seems that the real momentum for the term came during the 2000s, when Josef Motzfeldt (Inuit Ataqatigiit party) was minister of finance. This is based on counting the number of appearances of the word Selvbærende (self-sustaining) in relation to the economy in reports from the Advising Committee on Greenland's Economy (1997-2009), Political-Economic Reports (2002-2016), and the newspaper Atuagagdliutit (1861-1999). In early uses of the term, the primary meaning was connected to the substantial reduction of the block grant from Denmark (Selvstyrekommissionen, 2003), and the Greenlandic-Danish Self-Rule Commission pointed out that from 1980 to 2006 the block grant's share of gross national income (GNI) fell from $42 \%$ to $27 \%$. They concluded that Greenland had become "more economically self-sustaining" (Grønlandsk-Dansk Selvstyrekommission, 2008 , p. 51). This simple measure of the block grant's share of GNI doesn't say anything about the sustainability of the Greenlandic economy, and can not be used to predict whether the economy will remain independent in the future. The Economic Council of Greenland $(2012 ; 2014)$ has since been working to shift emphasis to issues of sustainability, arguing for solid public finances and higher living standards. Therefore the term "self-sustaining" has both an element of independence and an element of sustainability in it. If "independent economy" means not depending on external economic transfers or external administration, and "sustainable economy" means an economy that is not expected to crash, at least four objectives need to be met in Greenland to get a perfect self-sustaining economy:

- The block grant from Denmark should be terminated (independence).

- All responsibilities of government should be devolved to Greenland (independence). 
- Public finances should be solid (sustainability).

- Greenlanders should have a standard of living similar to the Nordic Countries (sustainability).

The block grant and devolution accounts for a needed $€ 610$ million per year (Greenland Statistics, 2017); solid public finances account for $€ 111$ million per year (Naalakkersuisut, 2016). If standard of living is measured as total consumption (public and private) per capita, another $€ 113$ million a year are needed to raise the standard of living in Greenland (Greenland Statistics, Danish Statistics, my calculation) This totals $€ 834$ million a year that would be needed for sustainable independence. This money could either be generated by reallocating public expenditure or increasing national production (value added). The public expenditure totalled $€ 1191$ million in 2015 (Naalakkersuisut, 2016), therefore reducing expenditure would mean a drastic move away from a modern welfare state. GDP in 2014 was $€ 1839$ million (Greenland Statistics, www.stat.gl), meaning that a sudden $45 \%$ increase in GDP would be needed. Any strategy for a selfsustaining economy would have to focus on a combination of reducing public expenditure and increasing the value added.

The report To the Benefit of Greenland (The Committee for Greenlandic Mineral Resources to the Benefit of Society, 2014), found it unrealistic and unsustainable that oil and minerals production would allow this kind of development within the next twenty to fifty years. It suggests a multipronged development strategy instead. It seems that working towards creating a more self-sustaining economy with more equal distribution of opportunities, is a meaningful goal for the Government of Greenland. One may wonder why there has not been an established overall politicaleconomic indicator measuring exactly that. It might even be the focus of further study, to create a meaningful "Self-Sustaining Economy Indicator."

\section{Review of Existing Political-Economic Indicators}

The following is a brief introduction to the two reports analyzed for this article. After the introduction of each report, an evaluation of the government's development of the use of political-economic indicators is given.

\subsection{The Joint Committee for Business Development in Greenland}

The premiers of Denmark and Greenland introduced the Joint Committee for Business Development in Greenland in 2003. This was a part of a complex of initiatives in the period, to start creating an overall business 
strategy. The joint committee was dominated by the Greenlandic business community and led by the Danish Business Council, suggesting that it was probably initiated by the Danish liberal government at the time. It was tasked with mapping the "limiting factors" for business development in Greenland to make recommendations on how to change them, and to strengthen the foundation for business development especially within the areas of education and social welfare. The joint committee used the creation of a self-sustaining economy as a waypoint for their work, and presented their take on this in the report called Without Business Development - No Welfare Development (Joint Committee, 2003).

One interesting thing about the report is that it predates the first Greenlandic strategy for education, which was made in 2005 (Naalakkersuisut, 2016). This means that the joint committee work was ahead of its time in connecting education to business development.

The Joint Committee has, in its ambition to set ... quantifiable goals, found it remarkable how lacking the data is in Greenland in quite central areas. ... This lessens the opportunities to target and plan necessary long-term initiatives. (p. 10)

The report was based on expert interviews in Greenland, a two day workshop called "Naleraq Camp," and a number of hearing rounds and online commenting possibilities. The joint committee developed goal indicators within six different fields:

- Education

- Labour market

- Competitiveness

- Infrastructure and housing

- Entrepreneurship

- Innovation.

They had a clear focus on privatization and development based on increased knowledge, and there were three overall recommendations from the joint committee:

- Working groups should clarify and specify each of the suggested initiatives, and prepare them for political decision making.

- A new independent council should be formed to ensure the following up on goals and initiatives. 
- The council should make an independent report annually to evaluate progress on the goal indicators.

Today, data is available in many areas for the actual development that occurred between 2004 and 2014, so it is possible to compare the extent that development was realized. It soon becomes clear, when doing so, that not all goals were achieved. The value for such comparisons is miniscule. More important is that neither working groups nor a new independent follow-up council were formed and annual reports were never created, at least not under the auspices of the joint committee.

\subsection{Sustainability and Growth Plan}

The Government Budget Act (Landstingslov nr. 8 af 29. oktober 1999 om Grønlands Hjemmestyres budget) requires the government to make an annual political-economic report to the parliament. The purpose of the report is to increase information about the economy of the central administration, and support the government and parliament in their considerations about economic development and prioritizing. The 2016 version included, as a new thing, a long-term plan called the "Sustainability and Growth Plan" (Naalakkersuisut, 2016).

The Sustainability and Growth Plan is built on a general objective of Greenland becoming more economic selfsustaining and in the long term independent of the block grant. (p. 2)

It has the dual purpose of securing future welfare by attaining long-term balance in public finances and growth and development, primarily in the private sector, with a differentiation of the economy. Four tracks of reform are identified:

- Increase the level of education.

- Promote growth and a multidirectional economy.

- Modernize the public sector, with better financial management and focus on preventive action.

- Increase self-support via welfare, tax, and housing reforms.

The report presents a number of specific goal indicators that should be achieved in the future, most of which are aimed at realization before 2030 . The stage of development is not consistent throughout the report. Some indicators are taken from sectoral strategy plans and others are not even defined yet. 
The advantage of setting up specific goals is that it becomes possible to evaluate whether society is moving in the right direction. (p. 30)

This suggests that there should be a follow up on the progress, partly in the future political-economic reports, and partly in specific reports on each sector. There is no close connection to the indicators in the joint committee report. Many of the old indicators are not continued, and those that are require a certain amount of interpretation to be comparable.

\subsection{The Influence of the Self-Rule Commissions}

By 2008, when the Greenlandic-Danish Self-Rule Commission published their report (Grønlandsk-Dansk Selvstyrekommission, 2008), the report of the joint committee seemed to no longer be politically important. In the five years leading up to that, there had been attempts to follow up on the joint committee report, for example the Business Development Strategy (Naalakkersuisut, 2005). At almost the same time as the joint committee report was published, the Greenlandic Self-Rule Commission (Selvstyrekommissionen, 2003) published their report, which was a forerunner to the 2008 Greenlandic-Danish Self-Rule Commission report. The joint committee report was more specific on economic goals, but in the end attaining self-rule received the most political attention and was achieved by 2009 .

In creating the sustainability and growth plan, the methodology of setting up economic indicators and following up afterwards, which was developed in the joint committee thirteen years earlier, was put back into use. The joint committee was special in the sense that it was the first time that political-economic indicators were used strategically in Greenland, but there was no immediate follow up on it despite what it had suggested. The sustainability and growth plan will most likely experience a much greater sense of ownership within the government since it is based on numerous reports made by several governmental departments and it has made its way into the annual political-economic report. In other words, the central administration seems to have learned a new way of working with the joint committee in 2003, but has yet to find a way to implement it. The sustainability and growth plan seems to be a serious attempt.

\section{Suggestions for Future Political-Economic Indicators}

In the following section, the theories of innovation and entrepreneurship are related to the report of the joint committee and the sustainability 
and growth plan in order to identify areas where future reports may be improved.

\subsection{Economic Development Connected to Natural Resources}

The political ambition to create a self-sustaining economy requires a mix of efforts. On the one hand, public expenditure needs to be at a sustainable level; on the other hand, total production needs to increase. Both the joint committee report and the sustainability and growth plan call for the regulation of government spending, and the latter is much more detailed on this point. When it comes to economic development, there is a huge difference in the approach of the two reports. The report of the joint committee focuses more on the push effect of raising the general competence level of the labour force, and the sustainability and growth plan focuses much more on diversifying the economy through the development of tourism and natural resources. Concerning the natural resources, the plan discusses two sectors, the fisheries and mineral resources. These two sectors are treated differently, in that mineral resources development are thought of in a broader context of competence development and processing, which is in accordance with innovationbased natural resource intensive development (INRID). This is contrary to the fisheries where the plan talks about modernization of the fishing fleet as an isolated thing from the rest of society. The only linkage of this modernization to other sectors is that it will free labour force for other sectors. A weak point in this respect, though, is that the plan assumes that these fishermen will get higher paid jobs and that "increased supply of labour ... increases the supply of jobs" (p. 85). According to INRID theory, the government should work actively to link the fisheries to other industries instead of leaving the responsibility to the market.

\subsection{An Entrepreneurial Culture}

According to entrepreneurship theory, new ventures are the drivers of economic change. Less focus is on whether they are new ventures in terms of new start-ups or existing firms succeeding in product or processinnovation. The National Systems of Entrepreneurship theory argues that a country's innovative capability depends not only on the institutional setting, but also the entrepreneurial attitudes, abilities, and aspirations of the population (Ács, 2016). That means that it is valuable to have some knowledge about individuals' dispositions towards entrepreneurship, as well as institutional data. 
Both the joint committee report and the sustainability and growth plan were written by experts, drawing on existing data from Greenland Statistics, and other similar sources. Neither of them are based on an explicit theoretical foundation for the model. Furthermore, there are no, or few, individual-level data to connect to the institutional-level data, as suggested in the GEDI index. It can be assumed that a GEDI type overview would make it easier to predict the outcome of the institutional adaptations, since institutions are not all that matter. It would increase the value of future reports to include survey data to get a better idea about what the people in Greenland are willing and able to do in order to achieve economic change.

\subsection{Implications for Innovation Policy}

Many of the economic indicators used in the two reports describe conditions that the government can only influence indirectly, such as private sector growth, drop-out rates, and so on. A focus on availability of data and knowledge is an obvious result of following up on political indicators, however it is the translation of the target indicators into a concrete institutional framework that is the strength of the reports. In principle, the connection of indicators to institutions makes it possible to test whether the institutions work. This is of course underlying the point made by Ács (2016), where indicators could also be an expression of changing attitudes, abilities, and aspirations. Thus, both reports are missing the individual level analysis in its ability to exclude the possibility that changes come in spite of policy.

The new technique that was introduced by the joint committee report was the use of indicators to design policy-one could say "to manage by numbers." The government needed to learn to manage by numbers, and the sustainability and growth plan shows that the government is learning this. Learning that takes place in the policy-making cycle is called "policy learning," and this is something the World Bank and OECD are dealing with in their Innovation Policy Platform (www.innovationpolicyplatform. org). In this framework, scholars are theorizing on how organizational capacities in different countries affect the effectiveness of innovation policy across the countries. A future innovation strategy for Greenland should of course take such concerns into account.

\section{Conclusion}

The purpose of this article was to find out how Greenland uses, and can use, political-economic indicators to move towards having a selfsustaining economy. Although a truly self-sustaining economy is not 
seen as a realistic possibility in the near future for Greenland, moving in that direction is seen as positive progress. Further studies are suggested to establish a meaningful political-economic indicator for the selfsustainability of the economy. A number of the elements that such an indicator should include have been identified here.

According to Ács's theory, a good methodology would combine individual level data with institutional level data in order to identify the blocking mechanisms. When identified, policy should address the blocking mechanisms and work proactively for innovation strategies that create linkages between the natural resource industries and the rest of society. With a strong innovation system, a country may avoid the resource curse and turn natural resources into economic development.

The general methodology established by the Joint Committee for Business Development in Greenland is still being used, and it has played an important role in establishing a systemic and systematic approach to innovation and business development. Although there has not been a direct follow up on the goals from 2003, the work completed by the government may be more continuous than it appears at first sight. The sustainability and growth plan will likely be more successful than the joint committee in shaping the future decision-making process. Following up on the sustainability and growth plan provides a strong potential for indicator-based management.

This, of course, raises the question of which data and measurements would be meaningful for finding the blocking mechanisms, and how to get the political system to address them afterwards. An obvious next step would be to try and apply the GEDI to Greenland, and evaluating if these measures provide useful information for developing the innovation system. Also, there is already a broad perspective in the sustainability and growth plan regarding mineral resources, including plans for building skills and processing capabilities. This broadness seems to be lacking when it comes to fisheries policy-at least in its representation in the sustainability and growth plan. This is another area that could be developed.

\section{Author}

Christian Wennecke is a special advisor at Greenland Business A/S and an independent researcher; all opinions in this article are those of the author, and not of Greenland Business A/S. 


\section{References}

Ács, Z. J., Autio, E., \& Szerb, L. (2014). National systems of entrepreneurship: Measurement issues and policy implications. Research Policy 43(3), 476-494.

Ács, Z., Szerb, L., \& Autio, E. (2016). Global Entrepreneurship Index 2016. The Global Entrepreneurship and Development Institute, Washington, DC, USA. https://thegedi.org/2016-global-entrepreneurship-index/

Andersen, A., et al. (2015). Natural resources, innovation and development. Open Access edition. Aalborg: Aalborg University Press.

Copenhagen Economics. (2013). Fiskeriets økonomiske fodaftryk $i$ Grønland. Report for Greenland Employers Association, 22 October 2013.

Davidsson, P. (2016). Researching entrepreneurship - Conceptualization and design. Switzerland: Springer International Publishing.

Economic Council of Greenland. (2012). Økonomisk Råds rapport 2012 Naturressourcer som vækststrategi. Report to Naalakkersuisut, Sep. 2012. Nuuk.

Economic Council of Greenland. (2014). Grønlands Økonomi. Report to Naalakkersuisut.

Fagerberg, J. (2013). Innovation - A new guide. TIK Working Papers on Innovation Studies. No. 20131119. University of Oslo, Centre for Technology, Innovation and Culture.

Fagerberg, J. (2015). Innovation policy, national innovation systems and economic performance: In search of a useful theoretical framework. Working paper, version 23 October 2015, Aalborg University.

Freuchen, P. (1931). Grønlandske Problemer. Steen Hasselbalchs forlag. Copenhagen.

Gilbert, B. A., Audretsch, D., \& McDougall, P. (2004). The emergence of entrepreneurship policy. Small Business Economics, 22(3/4), Special Issue on Entrepreneurship and the Demography of Firms and Industries (Apr-May, 2004)

Greenland Statistics. (2017.) Realøkonomisk fordeling af offentlige indtægter efter sektor, transaktion og tid. Published at Statistikbank, www.stat.gl. http://bank.stat.gl/pxweb/da/Greenland/Greenland OF OF30/OFXREAI. px/table/

Grønlandsk-Dansk Selvstyrekommission. (2008). Grønlandsk-Dansk Selvstyrekommissions betænkning om Selvstyre I Grønland. Report from the Greenlandic - Danish Self-Rule Commission, 17 April 2008.

Innovation Policy Platform. (2016). Policy learning. Retrieved from https://www. innovationpolicyplatform.org/content/policy-learning

Johansen, L.E. (1994). Åbningstale. Opening speech for Parliament of Greenland, Fall meeting, 30 September 1994. 
Landström, Hans et al. (2013) Innovation and entrepreneurship studies: One or two fields of research. New York: Springer Science + Business Media.

Lundvall, B-Å. (2007). National Innovation Systems - Analytical Concept and Development Tool. Industry and Innovation, 14(1), 95-119. London: Routledge.

Mytelka, L., \& Smith, K. (2002). Policy learning and innovation theory: An interactive and co-evolving process. Maastricht: United Nations University. INTECH.

Naalakkersuisut. (2005). Bedre rammer for erhvervsudviklingen - med ny erhvervsfremmestruktur. Naalakkersuisut. Nuuk.

Naalakkersuisut. (2016). Politisk-Økonomisk Beretning 2016. The Government's report on economic policy to the Parliament. Item 10, Spring meeting, 1 June 2016.

Olsen, T. (2005). I skyggen af kajakkerne. Grønlands politiske historie 1939 - 79. Danish interpretation by Kuupik Kleist. Forlaget Atuagkat. Viborg.

Rottbøll, E. (2015). Selvstændighed er et lys, der brænder inden i os. Dagbladet Politikken, 13 January 2015. København. Retrieved from https://www. information.dk/indland/2015/01/selvstaendighed-lys-braender-inden

Schumpeter, J. (1942). Capitalism, socialism and democracy. 2008 edition with introduction by Thomas K. McCraw. New York: HarperCollins.

Selvstyrekommissionen. (2003). Betænkning afgivet af Selvstyrekommissionen. Naalakkersuisut. Nuuk.

The Committee for Greenlandic Mineral Resources to the Benefit of Society. (2014). To the benefit of Greenland. Nuuk and Copenhagen: University of Copenhagen and University of Greenland.

The Joint Committee. (2003). Uden Erhvervsudvikling - ingen velfærdsudvikling. Nuuk: Greenland Home Rule Government. 